\title{
Sentido del tiempo y nacimiento del pensamiento histórico en el cristianismo desde sus orígenes hasta Eusebio de Cesarea ${ }^{1}$
}

\author{
Emanuela Prinzivalli
}

Universidad de La SAPIENZa, Roma

\section{EL TIEMPO Y EL HOMBRE: UNA RELACIÓN COMPLEJA}

Tiempo y espacio son las dimensiones de nuestra existencia, nosotros mismos somos tiempo y espacio: nuestro cuerpo, manifestación misma de nuestro ser, ocupa y representa un espacio; el transcurso del tiempo influye en él; nuestra memoria, además, dispone una articulación personal de los tiempos. Después, como existimos en relación con los demás, subsiste un tiempo colectivo, ya sea familiar, religioso, político. Las divisiones de estos "tiempos" vienen determinadas por los hombres, aunque tengan en cuenta el ciclo de la naturaleza, también temporal. Si nosotros somos nuestra memoria, estamos nutridos por ella, por tanto, por el pasado, es cierto que nuestra percepción del tiempo está orientada hacia el futuro. En definitiva, vivimos en una multiplicidad de percepciones y de dimensiones del tiempo. A todo lo dicho hasta ahora, que representa la experiencia común a todas las generaciones humanas, nuestro mundo contemporáneo ha añadido los resultados de la física relativa, con la consiguiente dificultad de conciliar el sentido común del tiempo con la teoría de la relatividad. Pero éste es un problema tan fascinante como ajeno a lo que ahora nos ocupa ${ }^{2}$. Estas breves palabras iniciales sirven únicamente para hacer comprender, si fuera necesario, la actualidad y complejidad del tema que abordamos.

1 Esta conferencia es la lectio que se me pidió durante el $X$ Seminario de Estudios Patrísticos organizado por Samuel Fernández, Manuel Correia y Fernando Soler, en las Facultades de Teología y de Filosofía de la Pontificia Universidad Católica de Chile entre el 29 de agosto al 1 de septiembre de 2017. Al texto entonces leído, le he ańadido las notas para su publicación escrita.

2 Para una primera información ver: C. Rovelli, L'ordine del tempo, Milano 2017. 
Nuestra pregunta es la siguiente: puesto que la articulación pública del tiempo heredada de Occidente es aquella marcada por el cristianismo, ¿cuándo y cómo emergieron entre los cristianos un sentido y una construcción específicos del tiempo? Hablar del tiempo implica, además, la asociación inmediata con la historia, entendida bien como el desarrollo de los acontecimientos humanos en el tiempo; bien como, según la definición de Marc Bloch, la ciencia de los hombres en el tiempo. ¿Cuándo y cómo comenzaron los cristianos a interesarse por su existencia en el tiempo y a considerarse sujetos de la historia?

Debo dar por descontado el punto de referencia historiográfico que todos tenemos en mente, el estudio clásico de Oscar Cullmann, Christus und die Zeit (Zollikon-Zürich 1946) -según el cual, el nacimiento y la muerte de Cristo asumen para sus seguidores una centralidad temporal tal que todo suceso viene juzgado en relación a ésta: por tanto, toda teología cristiana es historia bíblica- así como también las polémicas (pensemos en James Barr ${ }^{3}$ ) y aclaraciones posteriores, pero no puedo dejar de recordar que la cuestión del tiempo es fundamental en Occidente para la filosofía, para las artes y para el conocimiento en su totalidad. Propondré, pues, exclusivamente un recorrido personal, nutrido de la comparación con estos grandes y otros autores de los que trataré en el texto escrito.

\section{EL EVANGELIO Y EL KAIRÒS}

Cullmann y Barr concuerdan en un punto, incontrovertible: una reflexión abstracta sobre el tiempo no interesa a los autores que entraron a formar parte del Nuevo Testamento. De todos modos, es innegable que un sentimiento particular y urgente de la temporalidad estaba presente en un movimiento religioso que toma la iniciativa de un hombre cuyas primeras palabras, pronunciadas en el Evangelio de Marcos -que la mayor parte de los estudiosos considera aún hoy el más antiguo ${ }^{4}-$ son: "cumplido está el

3 J. BARR, Biblical Words for Time, London 1969.

4 La investigación más reciente sobre Marcion ha revivido el tema de un Ur Lukas: D.T. Roth, The Text of Marcion's Gospel, New Testament Tools, Studies and Documents 49, Leiden-Boston 2015; J.M. Lieu, Marcion and the Making of a Heretic. God and Scripture in the Second Century, Cambridge 2015; M. Klinghardt, Das älteste Evangelium und die Entstehung des kanonischen Evangelien, I-II Bände, Tübingen 2015; M. Vinzent, Marcion and the Dating of the Synoptic Gospels, Studia Patristica. Supplements 2, Leuven etc. 2014; P.A. Gramaglia, Marcione e il Vangelo di Luca. Un confronto con Matthias Klinghardt, Collana di Studi del Centro Interdipartimentale di Scienze Religiose, Torino 2017. 
kairòs y el reino de Dios está cercano; arrepentíos y creed en el Evangelio" (Mc 1,15). En este caso, debemos entender el término kairòs como un plazo o una extensión de tiempo ${ }^{5}$. El anuncio entrelaza, por tanto, de manera indisoluble realidad temporal y espacial. Realidad espacial, el reino, que, por otra parte, no es aquella que será categorizada más tarde en términos platónicos como ontológicamente superior e inmaterial, sino que, por el contrario, aunque invisible actualmente, contempla una transformación positiva de toda la realidad humana, como el dicho de Jesús sobre beber vino en el reino (Lc 22,18 y Mc 14,25, Mt 26,29) permite intuir. En el curso de la predicación del Nazareno, tal como aparece en la tradición sinóptica, el Reino de Dios se muestra como realidad ambivalente, no sólo espacialmente (está cercano, está lejano, está dentro, está fuera), sino también temporalmente (es ahora, será después). En cuanto prometido por Dios para el futuro, el reino manifiesta su dimensión escatológica; en cuanto reversión futura de toda situación de sufrimiento (véanse las bienaventuranzas), su entonación es específicamente apocalíptica porque el bien del eón futuro se contrapone al mal del presente; en cuanto realidad como acción en las manifestaciones de la misericordia de Dios que acontecen a través de Jesús de Nazaret (curaciones, perdón de los pecados) viene, sin embargo, a modificar la dicotomía apocalíptica entre el presente y el futuro, reintroduciendo en el presente, en el sentido escatológico de tiempo último que dedicar a la conversión, la acción soberanamente benéfica de Dios. El nexo establecido entre presente y futuro marca, por tanto, incluso en un horizonte cultural afín a los movimientos apocalípticos de la época, la originalidad del mensaje de Jesús. Tal conexión cambia el sentido del tiempo presente. Jesús valoriza, según la tradición sinóptica, la elección inmediata y decisiva de conversión del interlocutor y el acto de fe que lo pone de acuerdo con la voluntad de Dios, redimensionando objetivamente con ello la presencia amenazante del mal y la influencia de los demonios. El mal es una realidad aceptada como inevitable en el tiempo presente, pero no es ineludible para el ser humano. Por consiguiente, si, por un lado, el mensaje de Jesús, debido a la espera de la inminente

5 J. BARr, Biblical Words for Time, 127. Después de la crítica de Barr al enfoque terminológico para comprender el significado del tiempo en la Biblia, es mejor no insistir en este mismo argumento. Sin embargo, puede ser útil recordar, además del doble significado de kairòs (extensión del tiempo o momento decisivo), la polisemia del término aiôn: ver I. Ramelli- D. Konstan, Terms for Eternity: Aiônios and Ä̈dios in Classical and Christian Texts, Piscataway NI 2007. 
llegada de un reino de Dios, discontinuo respecto al orden del mundo circundante, entra de nuevo en el horizonte de sentido de las corrientes apocalípticas, por otro lado, se aleja de él porque, gracias a la fe en el ofrecimiento actual de la misericordia por parte de Dios y en la capacidad de los hombres de responder a ella, que acompaña a esta espera, no valora según un parámetro global y negativo el discurrir humano desplegado en el tiempo. La presencia del reino en las acciones que Dios dispone a través de Jesús es un anticipo, aunque parcial, como cuando Jesús afirma que, si ahuyenta a los demonios con el dedo de Dios, "sobre vosotros ha llegado el reino de Dios” (Q/Lc 13,29= Mt 8,11), dinámico, como en las parábolas en las que un hombre siembra un grano de mostaza que se convierte en un árbol grande y una mujer pone la levadura en tres medidas de harina y ve crecer el pan (Mt 13,31-33), pero también precario, si se atiende a la parábola -admitiendo que se remonte a Jesús- transmitida sólo en el Evangelio de Tomás, en la que la mujer que lleva un cántaro lleno de harina no se da cuenta de que el mango se ha roto y la harina se está saliendo: su descuido ha desperdiciado lo que le había sido dado (EvTm 97); o, de acuerdo con otra posible interpretación de la parábola, inesperado e impredecible en comparación con las intenciones de los seres humanos (como le sucedió a la mujer que esperaba llevar a casa la harina) ${ }^{6}$.

\section{DESPUÉS DE LA MUERTE DE JESÚS: LOS SEGUIDORES Y LA ESPERA DEL FIN}

El mensaje de Jesús, pues, comprende tanto el inicio de la realización de la promesa de Dios, como la espera de su cumplimiento, verosímilmente durante su propia vida. Pero la muerte infamante de Jesús sobre la cruz cambió la perspectiva. El movimiento nacido de Jesús, para sobrevivir a esta tragedia y, al mismo tiempo, para confirmar la misión y la persona extraordinaria del propio líder se concentra en un nuevo problema: si para la mayor parte de sus seguidores Jesús el crucificado es el mesías esperado, es necesario dar explicación al hecho de que el tiempo del reino

6 De hecho, la interpretación de esta parábola está abierta a varias soluciones: ver $S$. Gathercole, The Gospel of Thomas. Introduction and Commentary, Texts and Editions for New Testament Study 11, Leiden-Boston 2014, 549-554 (con una lista de las diferentes interpretaciones); A.D. DeConick, Recovering the Original «Gospel of Thomas». A History of the Gospel and its Growth, Library of New Testament Studies 286, New York 2005, 270-271 ; C. Gianotto, Il Vangelo secondo Tommaso e il problema storico di Gesù, en E. Prinzivalli (ed.), L'enigma Gesù. Fonti e metodi della ricerca storica, Aulamagna, 29, Roma 2017, 68-93, en especial: 92. 
de Dios no ha sido inaugurado con su venida, contrariamente a lo que prescribía el horizonte de espera. Los seguidores de Jesús posponen, pues, la inauguración del tiempo nuevo hasta una segunda venida gloriosa de Jesús como juez escatológico, empleando, también en este caso, imágenes y categorías difundidas en el judaísmo contemporáneo ${ }^{7}$. El contemporáneo y ulterior cambio de perspectiva relativo a las modalidades del anuncio evangélico a los gentiles, ya iniciado por los "helenistas", es llevado a cabo por Pablo con absoluta coherencia, por el cual Cristo se convierte en el autor exclusivo de la salvación para el Israel escatológico, ampliado a todas las gentes, prescindiendo de la pertenencia al Israel histórico. La urgencia escatológica de Jesús, que consideraba inminente la venida del Reino de Dios, viene sostenida por Pablo y se traduce en la consciencia de la precariedad de toda institución y costumbre política, religiosa, social, que el fiel respeta y a las que obedece aun sabiendo que están ya despojadas de sentido último: "Os digo, pues, hermanos, que el tiempo es corto [...] porque pasa la apariencia de este mundo" $\left(1\right.$ Cor 7,29. 31) ${ }^{8}$. Para Pablo el sentido del presente es negativo (Gálatas 4,3-5: tiempo malvado; Romanos 13,12: "la noche va muy avanzada y se acerca ya el día"), el reino para Pablo es prevalentemente futuro (1Cor 4,20; 1Cor 6,8.10; 1Cor 15,50; Gal 5,21), excepto cuando parece identificarse con los fieles de Jesús, considerados, universalmente y siempre con proyección escatológica, como el reino que entregar al Padre (1Cor 15,24-25), como confirma un pasaje de la Carta a los Romanos en el que el reino viene identificado con la justicia, la paz y la alegría en el Espíritu, o sea, con virtudes y dones que se presuponen ya presentes en la asamblea de los fieles (Rom 14,17).

Durante al menos un siglo y medio la reflexión subyacente sobre el tiempo hecha por los cristianos coincide con las respuestas que dar al problema del retraso del fin, es decir, del retraso de la venida gloriosa de Cristo, que aplaza más adelante la instauración del reino prometido y permite al mal y a las aflicciones reproducirse. Ante esta dificultad, la urgencia de las Iglesias es mantener la cohesión, la unión, el amor recíproco. Actúa a propósito un doble dispositivo: por un lado, las divisiones internas sirven

Ver A. Destro-M. Pesce, La muerte de Jesús. Investigación de un misterio, Estella 2015 y las consideraciones de E. Norelli, aquí retomadas, en Why Did Early Believers In Jesus Write Apocalypses? ZAC 20,1 (2016) 63-83, en especial: 64.

8 J. A. GaYtán Luna, Fin del mundo y destino final del hombre: La exégesis escatológica de I ad Corinthios 7,31, y 15,50 en la literatura cristiana antigua, Frankfurt am Main 2014, 18-19. 
para indicar que el fin está cerca de todos modos (así se expresa en los apocalipsis sinópticos y en la Didachè $e^{9}$ ) porque se insertan en las señales premonitorias de éste; por el otro, dado que la salvación no se le ofrece al que se separa de la comunidad, funcionan como aliciente para su recomposición. De la fe en la segunda venida (parusía) de Cristo durante la primera generación, tan repetida, incluso en los evangelios más tardíos como el de Lucas y el de Juan, de pretender que fuera originada por las propias palabras de Jesús, y que puede haber durado hasta finales del s. I (¿quién podía asegurar que en aquella época no hubiera todavía en alguna parte testigos oculares de Jesús?), se pasa a afirmaciones que trasladan el acento sobre la certeza de la parusia, justificando el retraso con la necesidad de la conversión de los pueblos. Así sucede en los Hechos de los Apóstoles, obra que algunos estudiosos pretenden leer como una primera historia de la iglesia ${ }^{10}$ y que, en cambio, tiene como fin la demostración del cumplimiento de la evangelización en vista del fin de los tiempos: si, por un lado, se niega la posibilidad de conocer los tiempos y los momentos $(1,6)$ por el advenimiento de lo que los apóstoles entienden como el futuro reino de Israel finalmente victorioso, por el otro, encamina el descenso del Espíritu a la conversión de las gentes que llevará al fin esperado: esto viene proclamado sea por Pedro, que liga la conversión a la reconstitución (apocatástasis) de todas las cosas (Hechos 3,21), sea por Pablo, que liga la conversión al juicio (Hechos 17,31).

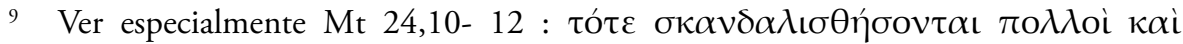

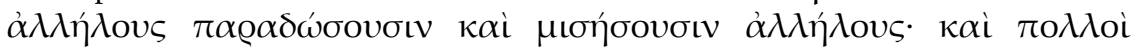

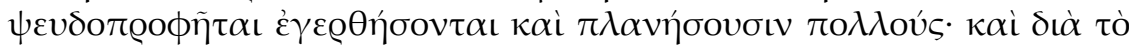

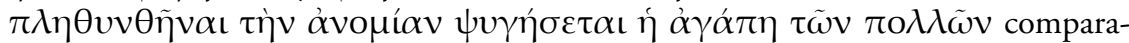

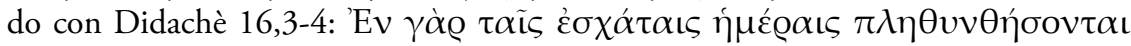

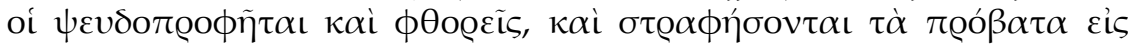

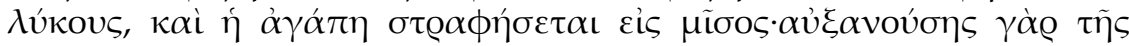

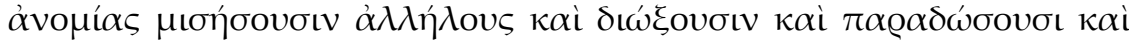

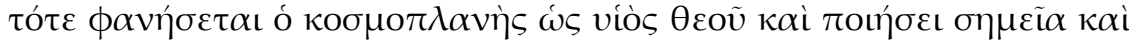

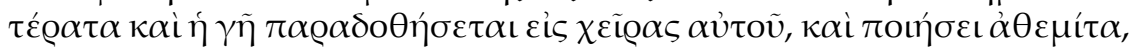

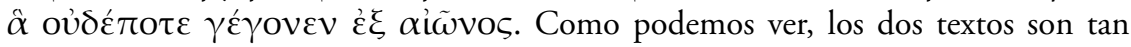
semejantes que hipotetizamos una fuente común con diferentes desarrollos en Mt y Didachè: ver K. Niederderwimmer, Die Didache, Kommentar zu den Apostolischen Vätern 1, Göttingen 1989, 248-50.

10 D. Marguerat, La première histoire du Christianisme. Les Actes des Apôtres, Lectio divina 180, Paris 1999; Id., Les Actes des Apôtres. Commentaire du Nouveau Testament, 2 vol., Genève 2015. 
La Segunda Carta de Pedro, rebatiendo a cuantos están dudosos y dicen que nada ha cambiado desde la primera creación, sostiene que, por el contrario, no todo ha permanecido como en la primera creación porque el mundo pereció con el diluvio y, si ahora se conserva, es por la benevolencia de Dios que quiere la conversión de "todos" $(3,9)$. No está clara la relación entre este augurio de salvación universal y la precedente admonición sobre la destrucción de los impíos ("en el día del juicio y de la perdición de los impíos” 3,7), pero es evidente que la lógica que preside la predicación de Jesús (esto es: el kairòs se ha cumplido y, por tanto, convertíos) se presenta a la inversa: convertíos para que el kairòs se cumpla (es decir, la venida gloriosa de Cristo en lugar del reino de Dios). Permanece inalterada la convicción de vivir en los últimos tiempos, que, sin embargo, ya no están cronológicamente determinados. La afirmación de Jesús sobre el día del Señor que llega de noche como un ladrón (Mt 24,43-44; Lc 12,3940) ya no convive, como en los evangelios y en Pablo, con la seguridad del cumplimiento dentro de la generación presente, pero asume la función de frenar cualquier ilación sobre los tiempos.

Otras dos afirmaciones de la Segunda Carta de Pedro atraen nuestra atención. El autor introduce un dato cronológico, dirigido a restablecer la fe en el cumplimiento: "ante el Señor, un día es como mil años y mil años como un día" $(3,8)$, que reformula todo lo que dice el salmo 90 (89lxx): "Porque mil años son a tus ojos como el día de ayer, que pasó; como una vigilia de la noche". Lo que significa que los últimos tiempos no pueden ser cuantificados con una medida humana, porque la medida de Dios es diferente. La segunda afirmación hace referencia a la espera de "nuevos cielos y tierra nueva" ("Son los nuevos cielos y una tierra nueva que nosotros esperamos según su promesa, donde habitará la justicia” 2Petr 3,13), según la expresión de Isaías 65,17 y 66,22, tras la destrucción del mundo actual. No tenemos idea de cuándo fue compuesto este texto, considerado por la crítica el más reciente entre los textos incluidos en el NT.

Los mil años y la nueva creación están presentes en el Apocalipsis de Juan que, a diferencia de los textos mencionados hasta ahora, frente a la exasperación de la espera y de las dudas consiguientes, se sirve del elemento propio de los apocalipsis: la garantía proporcionada por el vidente de poder vislumbrar la realidad de Dios y, por tanto, revelarla.

El Apocalipsis de Juan sitúa la cuestión del fin en términos más escandalosamente urgentes: “¿Hasta cuándo, Señor, Santo, Verdadero, no juz- 
garás y vengarás nuestra sangre en los que moran sobre la tierra?” $(6,10)$, poniéndola en boca de "los que habían sido degollados por la palabra de Dios" $(6,9)$ y la resuelve jugando con la doble posibilidad del vidente de llegar a la voluntad eterna de Dios, en el que la victoria sobre el mal ha sido ya obtenida, con el fin de dar una respuesta sobre el plano de la temporalidad transeúnte a los fieles que deben tener paciencia hasta que se complete el número de los muertos (no parece que exista para los justos otra posibilidad que la muerte). Los caídos por el Cordero recibirán satisfacción también sobre el plano de la temporalidad terrena, porque los mil años del encadenamiento de Satanás, antes del desencadenamiento y de la derrota definitiva del mal, están destinados a su reino. Los mil años indican un periodo de tiempo cumplido, una totalidad, en contraposición al tiempo breve o dividido en dos concedido a Satanás: cfr. Ap 13,5. Aquel que, entre los intérpretes contemporáneos ${ }^{11}$ (pero también entre los antiguos: pensemos en Orígenes ${ }^{12}$ y en Agustín ${ }^{13}$ ), quiera anular la dimensión escatológica de la narración del Apocalipsis de Juan, anula el objetivo último de la obra, que justamente a partir de la valoración negativa del tiempo presente (dominado por el imperio romano, la última bestia que concentra en sí misma todo el poder demoníaco), a causa de los sufrimientos de los fieles de Cristo y al consiguiente deseo de tranquilizarlos, se siente en la necesidad de trasladar del presente al futuro (de todas maneras próximo: véase el principio "para instruir a sus siervos sobre las cosas que han de suceder pronto" 1,1 ), estableciendo relaciones temporales entre el antes y el después.

11 E. Corsini, L’Apocalisse prima e dopo, Torino 1980 e Id., Apocalisse di Gesù Cristo secondo Giovanni, Torino 2002; U. Vanni, L'Apocalisse. Ermeneutica. Esegesi. Teologia, Bologna 1988. Una interpretación efectiva y pertinente del Apocalipsis y el milenio se encuentra en: The Anchor Bible. Revelation. Introducion, Translation and Commentary by J. Massyngberde Ford, New York etc. 1975; R.H. Mounce, The Book of Revelation, Grand Rapids 1997.

12 A. Monaci Castagno, Apocalisse ed escatologia nell'opera di Origene, Augustinianum 18 (1978) 139-151; ver ver también C. Mazzucco, L'Apocalisse nel Commento a Giovanni, en E. Prinzivalli (ed.), Il Commento a Giovanni di Origene. Il testo e i suoi contesti, Biblioteca di Adamantius 3 , Villa Verucchio 2005, 571-611.

13 De civitate dei 20: ver E. Prinzivalli, L'Apocalisse tra Ticonio e Agostino, in R. Guglielmetti (ed.), L'Apocalisse nel Medioevo. Atti del Convegno internazionale dell'Università degli studi di Milano e della Società internazionale per lo studio del Medioevo latino (S.I.S.M.E.L.), Gargnano sul Garda, 18-20 maggio 2009, Firenze 2011, 95113. 


\section{BERNABÉ Y LA PRIMERA PERIODIZACIÓN DE LA HISTORIA SEGÚN UN AUTOR “CRISTIANO”14}

También con la Epistola de Bernabé (=EpBar), de las primeras décadas del s. II, nos encontramos en plena atmósfera apocalíptica. La carta está dominada por la urgencia de desvelar un peligro en el interior del grupo de fieles que, según el autor, es el de caer en la observancia judaica, que Dios no ha entendido nunca que se cumpliese materialmente, sino según una perspectiva espiritual. En EpBar, mediante la recuperación de las tradiciones enóquicas y danielinas, se manifiesta de modo más evidente que en el Apocalipsis de Juan un intento de individuar el tiempo del fin no sólo sobre la base de señales internas de las iglesias (discordias, herejías, etc.), sino también basándose en datos históricos externos. En particular, Daniel (modificado) con la sucesión de las cuatro bestias y la evocación del pequeño cuerno que derriba tres reinos $(\mathrm{EpBar} 4,5)$ hace referencia a una situación histórica, difícil de determinar para nosotros, pero que a los destinatarios debía resultar accesible.

Si comparamos la EpBar con el Apocalipsis de Juan, constatamos mayor originalidad en esta última, ya que la visión de las dos bestias está inspirada en Dan 7, pero presenta imágenes y soluciones propias, mientras que la EpBar $(4,1-6)$ se limita a transmitir dos testimonia extraídos de Daniel 7. De todos modos, es precisamente la manera de presentar los testimonia, con pequeños añadidos (por ejemplo, el $\pi \alpha \varrho \alpha \phi v \alpha ́ \delta$ เov en EpBar 4,5 o sea "lateral", dicho del pequeño cuerno, o la forma adverbial ú $\phi$ 'ع́v "de un solo golpe” o, más importante aún, la variante que sustituye al término "rey" del que habla Daniel 7,24, el término $\beta \alpha \sigma \iota \lambda \varepsilon \tilde{\imath} \alpha \iota$ "reinos"), lo que constituye la prueba de que el autor (o la tradición llegada a él, que había modificado en el testimonium el texto de Daniel) tenía en mente una modalidad histórica precisa de disolución del imperio romano: por iniciativa de un jefe militar o cabecilla popular imprevisto o proveniente de un territorio marginal (como indica el adverbio "lateral"), tres reinos del imperio vienen conquistados con la consiguiente división del imperio ${ }^{15}$.

14 Ponemos "cristiano" entre comillas porque la palabra no figura en EpBar.

15 Para un análisis detallado del significado de estos cambios en el texto de Daniel ver mi comentario en: E. Prinzivalli-M- Simonetti, Seguendo Gesù. Testi cristiani delle origini, Milano 2015, 79-86. 
La auténtica novedad de la EpBar consiste en realidad en la recuperación de uno de los componentes estructurales de algunas tradiciones judías que el Apocalipsis de Juan había dejado casi en silencio: la periodización de la historia de la humanidad, que se expresa de la manera más férrea en el Libro de los Jubileos ${ }^{16}$ y el denominado Apocalipsis de las Diez Sema$n^{1} s^{17}$. Para nosotros, la EpBar es el primer intento en el ámbito cristiano de repartir el tiempo de este mundo. La novedad de la EpBar la constituye el haber insertado los mil años (equivalentes en EpBar como en 2Petr a un día del Señor) en el interior de un esquema de seis mil años (cap. 15), de los cuales el séptimo es el descanso de Dios, el único sábado que será lícito santificar porque se será santificado (por tanto, no el sábado de los judíos). Durante un tiempo se pensó ${ }^{18}$ que la concepción hexamilenaria estaba influenciada por cálculos iranios: en realidad puede ser perfectamente una deducción cristiana ${ }^{19}$, o exclusivamente de inspiración "bíblica", sobre la base de la combinación del dictado de Sal 89,4 con los seis días de la creación, en el ámbito de una tendencia a ofrecer divisiones de los tiempos definidas numéricamente presente en una parte del apocalíptica enóquica y en textos afines (Libro de los Jubileos). La valoración del tiempo actual, como en el Apocalipsis, es negativa: EpBar insiste "los días son malos" $(2,1)$. La herencia del bien es futura, pero el fiel obtiene consuelo en el conocimiento ofrecido por Dios por medio de los profetas acerca del pasado, el presente y el futuro porque "nos ha dado una primicia de las cosas futuras" $(1,7)$. En qué consiste esta primicia no viene dicho por el momento, pero del conjunto de la obra se deduce que se concentra en el mensaje y en la persona de Jesús, que entreabre aquel conocimiento de las Escrituras

16 Para obtener una información inicial ver: A. Diez Macho-M. Ángeles Navarro-M. Pérez Fernández, Introduccion general a los Apócrifos del Antiguo Testamento, Madrid 1984, 180-186.

17 El Apocalipsis de la Diez Semanas (93,1-10 + 91,11-17 está contenido en la Epistola de Henoc (93-105 de Henoc): ver Apócrifos del Antiguo Testamento. Tomo IV, Madrid 1984, 125-139. Ver C. Gianotto, Il millennio giudaico, ASE 15/1 (1998) 21-51, en especial: $27-28$.

18 J. DaniÉLOU, La typologie millénariste de la semaine dans le Christianisme primitif, Vigiliae Christianae 2 (1948) 1-16. Esta hipótesis, sin embargo, ha sido aun reavivada: O. Irshai, Dating the Eschaton: Jewish and Christian Apocalyptic Calculations in Late Antiquity, en Albert I. Baumgarten (ed.), Apocalyptic Time, Numen Book Series. Studies in the History of Religions 86, Leiden etc. 2000, 113-153.

19 O. ANDREI, La formazione di un modulo storiografico cristiano: dall'esamerone cosmico alle Chrongraphiae di Giulio Africano, Aevum 69 (1995) 147-170. 
negado al pueblo de Israel. En la EpBar el pequeño cuerno lateral (un rey o un reino) preludia - aunque no se identifique - la manifestación de un escándalo final sin más explicación (cap. 4). Otros textos de los orígenes (la Segunda carta a los Tesalonicenses y la Didachè) lo personalizan hablando de un "seductor del mundo" (Didachè 16,4) o del "Hombre de la iniquidad", "el hijo de la perdición" (2Tes. 2,3), comenzando a dibujar la figura de un adversario último que, asumiendo rasgos en apariencia salvíficos (Did. 16,4; 2Tes 2,9), constituirá la contrapartida de Jesucristo, creando la ilusión de la actuación en la Tierra de aquella venida gloriosa que los creyentes en Cristo habrían debido postergar a un momento futuro. La Segunda Carta a los Tesalonicenses presenta una ulterior particularidad, decisiva para nuestro discurso: mientras, por un lado testimonia también la persistencia de la espera del reino y de la parusía (1,5-10) manifiesta en las dificultades de los fieles, por otro lado, no sólo proporciona una explicación propia para el retraso del fin, que es la presencia de algo o alguien que "retiene" al último adversario ${ }^{20}$ (que será en el futuro fuente de continuas especulaciones acerca de su identidad), sino que también da esta explicación funcional para el alejamiento del tiempo final. Este último es un rasgo inédito: de hecho, las explicaciones examinadas precedentemente sobre el retraso de la parusía tenían la función opuesta de confirmar la esperanza de un próximo final del tiempo presente. ¿Por qué se comporta así el autor? Sólo podemos conjeturar que, según él, esta forma de posición sea la más adecuada para favorecer una convivencia serena en el interior del grupo con respecto a una espera espasmódica.

Hemos, por tanto, identificado un modo de concebir el tiempo entre los fieles de Jesús que de la espera del reino de Dios durante la generación presente (convertida, tras la muerte de Jesús y la fe en su resurrección, en espera de la venida gloriosa de Cristo y de su reino) se transforma en una espera proyectada en un futuro indefinido, aunque siempre más o menos cercano, que desemboca en una ocasión (EpBar) en un primer intento de repartición del tiempo de este mundo. No debemos pensar, no obstante, en una especie de línea evolutiva, ya que no conocemos más que de un

20 2Ts 2, 6-8: "Vosotros sabéis qué es lo que ahora le retiene, para que se manifieste en su momento oportuno. Porque el misterio de la impiedad ya está actuando. Tan sólo con que sea quitado de en medio el que ahora le retiene, entonces se manifestará el Impío, a quien el Señor destruirá con el soplo de su boca, y aniquilará con la manifestación de su Venida”. Ver M. Cacciari, Il potere che frena, Milano 2013 (con una antología final de textos patrísticos). 
modo aproximativo los ambientes de origen y la cronología de los textos llegados a nosotros que contienen tales consideraciones. Se trata de ideas que vienen circulando por vía de la comunicación oral primero o contemporáneamente a los escritos, que eran utilizados directamente por un número exiguo de personas. En este ámbito, la Escritura judía está considerada un medio de conocimiento del plan salvífico de Dios que se manifiesta a través de las acciones en beneficio de los fieles o en perjuicio de quien se le opone. Como consecuencia, subsiste un cierto interés, limitado, por el plano histórico de los eventos, en referencia sobre todo a la historia de Israel, diversamente dirigida al anuncio de Jesús, o a la individualización del poder imperial como elemento implicado y determinante en los acontecimientos del fin de los tiempos.

\section{El EVANGELIO DE TOMÁS Y LAS PALABRAS SIN TIEMPO}

A esta humus que, a pesar de las desilusiones, desconsuelo y temores, privilegia la espera, se contrapone, al inicio del s. II, otra línea que suspende todo interés por el futuro, en beneficio de una relación directa e íntima con las perspectivas de salvación. Podemos citar, como testimonio de tal planteamiento al Evangelio de Tomás, en la redacción copta descubierta en Nag Hammadi, que se remonta probablemente el original griego a mediados del s. II. He aquí una de sus afirmaciones: "Beato aquel que se sitúa al inicio: porque conocerá el fin y no experimentará la muerte” (Tm 18). Es probable que este evangelio inicialmente bebiera de las mismas tradiciones conocidas por los sinópticos y que tuviera un desarrollo paralelo a ellos, cuya particularidad se encuentra en el hecho de que sólo las palabras (logoi) de Jesús constituyen la fuente de salvación. Tratándose de logoi privados de un marco narrativo es natural que el Evangelio de Tomás creciera con la continua incorporación de material nuevo (rolling corpus). Según la convincente reconstrucción de DeConick ${ }^{21}$, que desmonta convicciones precedentes, el estrato más antiguo de los logoi está impregnado de una espera espasmódica del reino de Dios en función de la transformación del mundo y del juicio escatológico. La desilusión consecuente a la ausente llegada del reino habría tenido como resultado, en los grupos de creyentes que elaboraron los estratos sucesivos del Evangelio, la interiorización del

21 A.D. DeConick, Recovering the Original "Gospel of Thomas"; Ead., The Original Gospel of Thomas. With a Commentary and New English Translation of the Complete Gospel, London-New York 2007. 
concepto de reino y la proyección de las comunidades de referencia hacia un fuerte compromiso ético y rigorista ${ }^{22}$. El Evangelio de Tomás, tal como se ha conservado, puede ser leído en sentido gnóstico, pero no es gnóstico: es una lectura mística y existencial del anuncio evangélico. No hay un tiempo en los logoi de Jesús, que están suspendidos en la atemporalidad del "viviente". De la inminencia del eschaton se pasa a su inmanencia ${ }^{23}$.

\section{LOS GNÓSTICOS Y LA HISTORIA DESPRECIADA}

Oscar Cullmann tenía razón al subrayar cómo en los orígenes (alrededor de los 150 primeros años) los fieles de Jesucristo sintieron y razonaron con base en la tripartición temporal: antes -ahora- después y no con base en la contraposición espacial aquí abajo -el más allá. Sobre todo, la distinción que hacían entre dimensión terrenal/visible y dimensión celeste/ invisible -tan evidente en el Apocalipsis de Juan, que fundamenta el confort que dar a los perseguidos justamente en la posibilidad dada al vidente de superar la barrera que impide alcanzar la invisible- no presupone una diferencia ontológica entre las dos dimensiones. La realidad creada por Dios, de hecho, es única y puede ser destruida por Dios para ser recreada según una transformación radical, pero siempre como realidad comprensible y visible para los seres humanos. Esto es tan cierto que el anuncio mesiánico de los "cielos nuevos y tierra nueva" (Ap 21,1: cfr. Is 65,17 y 66,22) llega escatológicamente a la unificación de las dos dimensiones, visible e invisible, en la morada de Dios con los hombres, representada por el descenso de la Jerusalén del cielo (Ap 21,3). No podía ser de otro modo en un movimiento religioso que había heredado del judaísmo fariseo la creencia en la resurrección de los muertos, que implica de por sí la permanencia, aunque sea transfigurada (cfr. lo que dice Pablo sobre la liberación de la creación de la esclavitud de la corrupción en Rom 8,19), de un espacio análogo al espacio mismo de los cuerpos. Solamente frente a las repetidas objeciones que provenían de quien pertenecía a un mundo cultural diferente -el grecorromano- se desarrolló una reflexión compleja que, por un lado, salvaguardaba, y en algunos casos exasperaba, la carnalidad física de los cuerpos resucitados y, por otro lado, buscaba enrarecer

22 M. Grosso, Norme etiche e formazione comunitaria nel Vangelo secondo Tommaso : quali regole per quale comunità?, ASE 28/1 (2011) 59-76.

23 Esta formulación efectiva es de M. Grosso, Le parole che sconfiggono la morte, en Id., Vangelo secondo Tommaso. Introduzione, traduzione e commento, Roma 2011, 36. 
lo máximo posible el ambiente (celeste) de su vida en la eternidad (una línea que tendrá éxito en Occidente, pensemos en Agustín, mientras que quedará más difuminada en Oriente) ${ }^{24}$.

En cualquier caso, la persistencia del mal en el tiempo actual abre la puerta a perspectivas potencialmente dualísticas a nivel ontológico, extremando la oposición dualística de los tiempos (aiônes) de la tradición enóquica. Para algunos grupos de fieles la perspectiva salvífica del Cristo redentor crucificado da un vuelco para interesar el mundo divino, del que el mundo humano es un producto degradado. Se trata de un paso más allá con respecto a la tradición enóquica ${ }^{25}$ : ésta atribuía el mal del mundo/eón actual a una contaminación/culpa de la que se habían hecho responsables unos seres angélicos (los Vigilantes), pertenecientes a la esfera sobrehumana/divina. Las consecuencias de esta culpa recaían también y sobre todo sobre los seres humanos, incapaces de liberarse de ellas si no es por intervención divina. En el gnosticismo, en cambio, el caso de la culpa y de la redención es todo intradivino ${ }^{26}$. Para los valentinianos la realidad terrenal y humana está considerada el resultado de la degradación del mundo divi-

24 Sobre la doctrina de la resurrección ver: E. Prinzivalli, La risurrezione nei Padri, en Morte-Risurrezione. Dizionario di Spiritualità Biblico-Patristica, Roma 2007, 169 288; C. Walker Bynum, The Resurrection of the Body in Western Christianity, 2001336, New York 1995.

25 Sobre las relaciones entre apocalíptica enóquica y gnosticismo, vistas anteriormente como polos opuestos por la crítica, cfr. G.W.E. Nickelsburg, 1 Enoch 1: A Commentary on the Book of 1 Enoch, Chapters 1-36; 81-108, Minneapolis 2001, 37-41 y el primer capítulo de F. Berno, Il libro aperto. Indagine sulla ricezione valentiniana della tradizione letteraria enochica, Brescia 2018 (sub prelo)

26 La bibliografía sobre el gnosticismo es muy copiosa, tanto que algunos quieren descartar este sector de la investigación científica (ver M.A. Williams, Rethinking “Gnosticism”. An Argument for Dismantling a Dubious Category, Princeton 1999):). Otra prueba del fervor por este tipo de investigación es la nueva revista Gnosis. Journal of Gnostic Studies (2016-) "devoted to the study of Gnostic religious currents from the ancient world to the modern", también utilizando nuevos enfoques "such a cognitive science, cognitive linguistics, social memory, psychology, ethnography, sociology, and literary theory". Me limitaré a señalar algunos estudios generales: A. Magris, $\mathrm{La}$ logica del pensiero gnostico, Brescia 2012; D. Brakke, The Gnostics. Mith, Ritual and Diversity in Early Christianity, Cambridge 2010; Ch. Markschies, Gnosis: an Introduction, translated by John Bowden, London 2003. 
no (plêrôma), la materia es su producto espurio extremo ${ }^{27}$. La circunstancia divina está temporalmente dividida: en la denominada Gran Noticia transmitida por Ireneo el Prepadre o Abismo, eterno (aïdios) y engendrado, está junto a su pensamiento (ennoia) en los tiempos infinitos (en apeirois aiôsi). El adverbio pote (en un determinado momento) señala el inicio cronológico del proceso de emanación querido por el Prepadre y los seres emanados de la primera pareja son llamados colectivamente aiônes, salvo que tengan cada uno un nombre propio, que revela la función de cada uno. Es como decir que, en el pensamiento valentiniano, de un primer principio insondable y eterno brota el tiempo divino determinado por la sucesión de los eones, dispuestos según una taxis descendiente, dado que la culpa se verifica en el último eón, Sophia, que es a su vez el más reciente. También la interpretación bíblica realizada por los valentinianos confirma la división temporal del mundo divino: el misterio de la emanación de los eones (Adv. haer. I,3), de hecho, viene revelado por la suma de las horas (30) en las que los trabajadores, según la parábola de Mt 20, son enviados a la viña; la Carta a los Efesios cuando dice "en todas las generaciones por los eones del eón” (Ef 3,21), indica el orden. La llegada de Cristo Salvador (perteneciente al mundo divino y dotado sólo de una apariencia humana) "en los últimos tiempos del mundo" (en tois eschatois tou kosmou chronois) tiene la función de revelar la pasión de Sophia fuera del mundo divino ${ }^{28} \mathrm{y}$ cuanto acaeció dentro y fuera del pleroma: El mundo terreno, pues, es el escenario transeúnte de los eventos acaecidos en el divino, cuya representación/revelación por parte del Salvador sirve para desgarrar las tinieblas de la ignorancia en los espirituales y para iniciar el camino de su ascenso hacia el divino, al que pertenecen ontológicamente.

Los nexos temporales son mantenidos y dividen sea el suceso pleromático, sea aquel externo al pleroma. Los eventos externos, que llamaremos la historia humana, reciben un significado, en el plano simbólico, sólo en relación a los acontecimientos del mundo divino, sean aquellos de Sophia Achamoth, sean aquellos de las semillas espirituales dispersadas por ella.

27 G. LetTIERI, It Doesn't Matter. Le metamorfosi della materia nel cristianesimo antico e nei dualismi teologici, en D. Giovannozzi-M. Veneziani (edd.), Materia. XIII Colloquio Internazionale Lessico Intellettuale Europeo - Roma 7-9 gennaio 2010, Firenze 2011, 75-173.

28 Adv.haer. I 8,2 : "El Señor ha venido a sufrir en los últimos tiempos del mundo para mostrar la pasión que tomó el último de los Eones y con este fin ha mostrado el fin de la actividad en torno a los Eones". 
Los acontecimientos que no participan de esta relación son indiferentes para el gnóstico. La perspectiva escatológico-apocalíptica, por tanto, no queda en absoluto anulada: permanece, sin embargo, entendida igualmente, aunque más bien cambia de dirección. Se espera, efectivamente, con ansia el fin salvífico, pero éste no concierne al mundo visible y material $^{29}$, que será aniquilado, sino a aquel invisible y espiritual.

Marción es más radical que los gnósticos al oponer el Dios creador, justo y vengativo, al Dios sumo y bueno ${ }^{30}$. La ausencia de toda conexión o derivación entre las dos entidades divinas (según el parecer de la mayoría de los estudiosos que intentan reconstruir su pensamiento), conduce a una aporía que fue destacada por los polemistas antiguos y concierne precisamente a los tiempos o, mejor, a su cumplimiento: mientras, en efecto, el pensamiento "ortodoxo" puede justificar el retraso en la venida del Hijo del único Dios creador con el plan providencial que escoge el momento más adecuado, Marción no puede servirse de una explicación similar y el kairòs de la venida del Salvador permanece inexplicado, aunque, por eso mismo, con valor absoluto.

\section{LAS PROMESAS DE DIOS Y EL RESCATE DE LA HISTORIA HUMANA}

A los ojos de los cristianos que mantenían la herencia judía, la doctrina de los gnósticos y los marcionitas se configura como un completo trastorno de la óptica bajo la que mirar a Dios, a la identidad del ser humano y al mundo circundante. La reacción no tardó en manifestarse, desarrollándose en varias direcciones. Una de ellas fue el desarrollo de la doctrina milenarista. Encontramos ya los mil años en el Apocalipsis de Juan, pero la idea de un tiempo intermedio de reinado de los justos no está aislada, es más, estaba difundida entre la literatura judía apocalíptica en torno a la era vulgar. La encontramos de nuevo en 2Baruc, 29-30 y en IV Esdras 7,2635, donde vienen presentadas diversas duraciones para el reino intermedio (400 años para IV Esdras, duración no especificada en $2 \mathrm{Bar})^{31}$ y diversas

29 Ver, por ejemplo, fr. 4 Valentino; Ipostasi degli arconti 97,1-20 (NHC II,4); Sull'origine del mondo 125,23-127,17 (NHC II,5 ; NHC XIII,2) : N. Denzey Lewis, I manoscritti di Nag Hammadi. Una biblioteca gnostica del IV secolo. Edizione italiana a cura di M. Grosso, Roma 2014 (ed. orig. Oxford 2013), 213-239.

30 Acerca de Marción, además de los estudios citados en la nota 4, ver: S. Moll, The Arch-Heretic Marcion (WUNT 250), Tübingen 2010.

31 C. Gianotto, Il millenarismo giudaico, ASE 15/1 (1998) 21-51. 
modalidades (en IV Esdras el mesías y los justos vivientes en el reino mueren al final del reinado y todo vuelve al silencio primigenio antes de ser recreado), pero la idea de fondo está clara: confiar en un reinado terrenal del mesías con los justos vivientes en ese momento o con los resucitados, para que la fracción final del tiempo histórico quede liberada del mal. De todas formas, en el Apocalipsis de Juan, que describe tras los mil años el asalto de Gog y Magog, el reino no ocupa el extremo de la historia porque al final de este periodo las fuerzas del mal se desencadenan de nuevo. Los comentaristas modernos asocian esta idea a la tradición enóquica, donde, en efecto, está presente la idea del encadenamiento temporal del diablo ${ }^{32}$ : normalmente se cita 1 Enoch 10,6-12, donde, sin embargo, al encadenamiento por setenta generaciones le sigue directamente la destrucción, y 1 Enoch 18-19, donde a los diez mil años del encadenamiento parece seguir de nuevo la condena definitiva. En suma, en el Apocalipsis de Juan viene precisado lo que en la tradición enóquica permanece, en cambio, indefinido (o en absoluto especificado) y que ha creado evidentemente un problema teórico a los que retomaron sucesivamente la doctrina del milenio: ¿cómo es posible que la parte final de este eón sea todavía presa del mal después del reino de Cristo, siendo que este mal al final viene destruido? No puede ser casual, en mi opinión, que tanto Justino como Ireneo abandonen la secuencia de Juan y hagan terminar la historia de este eón con el reino milenario.

En el Diálogo con Trifón de Justino descubrimos la presencia de un dossier en relación a algunos aspectos del milenarismo. Por un lado, muestra una consonancia extraordinaria con El libro de los Jubileos (IV,29), un texto judío que sufre la influencia de la tradición enóquica, aunque remodelándola. Como en los Jubileos, Justino propone la idea de que Adán efectivamente murió, como había predicho Dios, el día en que, transgrediendo su mandato, comió del árbol: si, en efecto, un día del Señor equivale a mil años, Adán muere setenta años antes de los mil y, por tanto, muere el mismo día en que se come la fruta prohibida. Por otro lado, Justino evoca al Tritoisaías y, en particular, al versículo "según los días de los árboles serán los días de mi pueblo” (Is 65,22), haciendo explícito un nexo entre el número mil y la promesa de vida, con el fin de sustentar posteriormente la doctrina milenarista. Además, menciona también a Ezequiel y "los otros profetas", aunque sin citar ningún pasaje de apoyo sacado de éstos.

32 L'Apocalisse di Giovanni, a cura di E. Lupieri, Milano, 1999, 309. 
En este dossier, finalmente, aparece también el Apocalipsis, confirmando todo lo que Justino ha mantenido precedentemente, esto es: "aquellos que creen en nuestro Cristo habrán transcurrido mil años en Jerusalén, tras lo cual habrá una resurrección general y, en una palabra: eterna, para todos indistintamente y, por tanto, el juicio" (Dial. 81,4). Ahora, es evidente que la sucesión de los eventos está modificada con respecto al cap. 20 del Apocalipsis. De hecho, después del milenio Justino coloca directamente la resurrección general y el juicio, sin mencionar palabra sobre el posterior desencadenamiento de las fuerzas del mal tras el milenio. Y no sólo: aquí, e incluso antes, Justino insiste en la localización del reino en una Jerusalén reconstruida y grandiosa, aspecto este, sin embargo, apenas esbozado y casi omitido en el Apocalipsis, que no habla de la reconstrucción de Jerusalén, haciendo referencia únicamente, tras el milenio, al asedio de la "ciudad amada" (o sea Jerusalén) por parte de las fuerzas del mal y espera más bien el descenso de la Jerusalén de lo alto. En el Apocalipsis es como si Jerusalén pudiera ser mencionada con su nombre sólo después de la desaparición definitiva del mal.

Justino, por tanto, lee el Apocalipsis a la luz de una tradición que englobó la aspiración más fuerte del judaísmo de la época, aquella de la reconstrucción de Jerusalén, destruida hacía poco por el ejército de Adriano, pero probablemente no es ajena a esta recuperación la voluntad de oponerse a la depreciación de la historia judía llevada a cabo por movimientos dualistas y al ataque de los que "blasfeman contra el Dios de Abraham, de Isaac y de Jacob y afirman que no existe la resurrección de los muertos”. El milenio, precisamente, refuerza la doctrina de la resurrección, asegurando un lugar terrenal donde los justos resucitados pueden disfrutar de los bienes prometidos por los profetas y confirmando, por consiguiente, que un solo Dios promete y cumple las promesas, en contraposición a Marción y los gnósticos. El grupo de los beneficiarios se amplía, en consecuencia, a todos los justos, incluidos aquellos nacidos antes de Cristo, con respecto al limitado grupo de los "degollados" contemplado por el vidente Juan. Incluso la precisión de la muerte efectiva de Adán el día en que desobedeció no es ajena a este empeño apologético, en contra de los que consideraban al dios veterotestamentario un embustero. El apelarse nuevamente a los profetas tiene, por tanto, el objetivo de confirmar la continuidad de las promesas del único Dios. 
En Ireneo constatamos una doctrina milenaria elaborada para contrastar, punto por punto, el pesimismo de los movimientos dualistas con respecto al mundo terrenal y la visión de un rescate terrenal y material del mundo y del hombre en el reino y después de él. Nos alejaría demasiado de nuestro propósito detallar minuciosamente los argumentos presentados por Ireneo sobre las posibles objeciones de los adversarios. Es significativa la multiplicación de explicaciones, consideradas todas posibles, del famoso versículo de Gen 2,17 ("el día que de él comieres, ciertamente morirás"), entre las que está también la presentada por Justino y los Jubileos (Adv. haer. V, 23,2). A Ireneo, que ensambla los puntos presentes en varias tradiciones, debemos, como es sabido, la construcción del personaje del Anticristo: éste es la falsificación de Cristo y constituye el último obstáculo para los creyentes, sujetos a la tentación derivada de sus prodigios.

Podemos decir que es con Ireneo con quien aparece una primera interpretación elaborada con marca cristiana de la historia universal. Esto se debe a su meditación orgánica sobre Daniel 7, Daniel 2 y Apoc 13. La función principal del Anticristo es la de materializar las promesas de reivindicación política difundidas entre los judíos, entre ellas la del traslado del reino a Jerusalén ( $A d v$. haer. V, 25,4), en la que el templo, precisa Ireneo, ha sido hecho por la voluntad de Dios (V, 25,2). Pero al final el engaño del Anticristo se revela justamente con la profanación del templo de Dios. Por consiguiente: por un lado, Ireneo, en contra de los dualistas, confirma que el templo es prescripción del único Dios verdadero, por otro, en contra de los judíos, denuncia la falacia de sus esperanzas porque con la llegada de Cristo el templo es superado y el que espera su reconstrucción es presa del diablo. El Anticristo, simbolizado por la bestia que sale del mar en el Apocalipsis, según Ireneo, representa el último poder terrenal, que pone fin al imperio romano, simbolizado, según la tradición, por la cuarta bestia de Daniel 7, y alimenta con el engaño las esperanzas de los judíos, cubriendo así el último segmento de tiempo dominado por el mal, pero no tiene la última palabra sobre la historia humana. El tiempo de su reinado es, en efecto, un tiempo dividido, incompleto:

Mas una vez que haya devastado todas las cosas en el mundo, gobernará tres años y seis meses y tomará asiento en el Templo de Jerusalén. Entonces vendrá de los cielos el Señor, entre nubes, en la gloria del Padre para arrojarle a él y a sus seguidores al estanque de fuego, e implantar para los justos los tiempos del reino, a saber, el descanso, el día 
séptimo santificado, y otorgar a Abrahán la herencia prometida. En el cual reino dice el Señor muchos venidos del oriente y del occidente se recostaran a la mesa con Abrahán, Isaac y Jacob ${ }^{33}$.

El milenio, introducido así, como tiempo final de la historia, tras seis milenios, está inserto orgánicamente en una visión del mundo y de los hombres opuesta a la gnóstica ${ }^{34}$. Los valentinianos proponían una taxis, un orden, en el mundo divino, en el que los espirituales anhelan reunirse "inmediatamente después de la muerte" (Adv. haer. V, 31,1): Ireneo les reprocha que no conocen la taxis del progreso y "de la resurrección", que comporta sobre todo una estancia del alma tras la muerte "en la región invisible asignada por Dios" ( $A d v$. haer. V 31,2), después, la resurrección de los justos en el reino (milenario) que sirve para ejercitarse en la incorruptibilidad, sobre tierra renovada y reconducida a la situación originaria (aquella edénica). Como fundamento de tales expectativas se sitúa la valoración positiva de la creación en todos sus aspectos, partiendo de aquellos materiales del mundo y del hombre, entendido en su unidad psicofísica, por los que la visión de Dios no puede ser dada al alma privada de cuerpo (que, de hecho, permanece confinada en las regiones invisibles hasta la resurrección). La historia humana se desarrolla según el plan providencial del único Dios y, al término de ésta, existe la posibilidad para la creación de desplegar finalmente todo su potencial, como nunca antes podía haber hecho, por los efectos nocivos del pecado de los protoplastos: el poder terrenal está, en todo caso, a este lado de esta liberación, confinado en su espacio y en un término concreto.

El cuidado por no privar de ningún modo a la materia de la mirada de Dios conduce a Ireneo a precisar que la sustancia material permanecerá incluso después del fin del milenio, sirviéndose del versículo paulino de 1 Cor 7,31 ("pasa la apariencia de este mundo"): cuando se dé la segunda renovación siguiente al reino milenario, los seres humanos

33 Adv. haer. V, 30,4; A. Orbe, Teología de San Ireneo. Comentario al Libro V del "Adversus haereses", Biblioteca de Autores Cristianos 33, Madrid-Toledo 1988, 279-285.

34 Me complace mencionar, en este sentido, a Manuel Lacunza (Santiago, Chile 1731-Imola, Italia, 1801), una gran figura intelectual de Chile, que pudo mostrar, a partir de una lectura cuidadosa de los textos proféticos, la vitalidad y el profundo sentido del milenarismo: ver F. Parra Carrasco, El reino que ha de venir. Historia y esperanza en la obra de Manuel Lacunza, Santiago de Chile 2011. 
Pues por ser los hombres verdaderos, conviene sea también verdadera su implantación; y que, lejos de caer en lo insubsistente, progresen en el ser. En efecto, no desaparece el substrato ni la materia de la creación - verdadero y firme como es quien la estableció -, sino que pasa la figura de este mundo, a saber (del substrato y materia) en que tuvo lugar la transgresión, pues en ellos envejeció el hombre [...]. Una vez que pase esta figura y se renueve el hombre y madure para la incorruptela, de suerte que ya no pueda envejecer, habrá un cielo nuevo y una tierra nueva, en los que perseverará el hombre nuevo, conversando siempre novedades con Dios ${ }^{35}$.

Ireneo responde evidentemente a una preocupación que le originaban las opuestas especulaciones dualistas, que hacían descender el aniquilamiento de la sustancia material de su extrañeza al Dios sumo. Un autor cristiano un poco anterior, como el de la Segunda carta de Pedro, se limitaba a proclamar la destrucción del cosmos (3,6 y 10).

Como hemos podido observar, la espera escatológica de Ireneo, contrariamente a los gnósticos y los marcionitas, está dirigida hacia el intento de establecer un orden de acontecimientos que son futuros, a pesar de que el horizonte de los sucesos finales permanece indeterminado.

\section{EL HORIZONTE HISTÓRICO SE PRECISA: LA REFLEXIÓN DE HIPÓLITO}

A los gnósticos no les importaba la historia factual. Por el contrario, el movimiento montanista propone nuevamente no sólo las esperanzas de un fin próximo, sino también actitudes separatistas con la sociedad con la que los cristianos intentaban convivir. Contra estas últimas Hipólito retoma y modifica el planteamiento de Ireneo, componiendo por primera vez dos obras destinadas a hablar de los últimos tiempos: el de Christo et de Antichristo y el De Daniel.

Él vuelve a proponer el paralelismo, instaurado ya por Melitón de Sardes, entre los comienzos del imperio romano y el nacimiento de Cristo, pero dándole un sentido negativo: el universalismo del imperio, dirigido a la guerra de conquista, es en sí mismo la falsificación del mensaje universal de Cristo. Como Ireneo, Hipólito despliega la historia en siete milenios. Pero esta vez la división está orientada ante todo a un enfriamiento de la espera escatológica que, dirigida por "jefes de iglesia" desproveídos que

35 Adv. haer. V, 36,1; A. Orbe, Teología de San Ireneo... , 557-573. Ver J.A. Gaytán Luna, Fin del mundo y destino final del hombre, 45-49. 
malinterpretan las Escrituras, podría poner en peligro la convivencia civil y la vida social, como sucede en Siria y en el Ponto, donde a los fieles se les pone muy nerviosos creyendo en la parusía inminente, hasta el punto de que los unos se ponen a vagar por el desierto para ir al encuentro de Cristo y los otros dejan de trabajar para dedicarse a la penitencia (Comentario a Daniel 4,18 y 19). Pero el fin no está cerca. Hipólito, en efecto, establece el nacimiento de Cristo en el 5500, o sea a mediados del sexto milenio ${ }^{36}$, dejando un lapso de tiempo todavía muy largo entre su época y el fin, que podríamos establecer en aproximadamente trescientos años.

Hipólito utiliza, a la par que Ireneo ${ }^{37}$, la combinación de Daniel 2, Daniel 7 y Apocalipsis 13. Los dos intérpretes cristianos coinciden en la identificación de la cuarta bestia de Daniel con el imperio romano, probablemente por dependencia de una tradición judía ya establecida ${ }^{38}$; ambos comparten la idea de la alternancia histórica como dominadores de babilonios, persas, griegos y romanos ${ }^{39}$ y la profecía de la división del imperio de Roma en diez reinos ${ }^{40}$, que Hipólito entiende como "democracias", su-

36 Hipólito, Comentario a Daniel 4,23: "Si calculamos el tiempo transcurrido desde la creación del mundo y desde Adán el problema se aclara. La primera parusía de nuestro Seńor, aquella en la carne, por la que nació en Belén, tuvo lugar el octavo día antes de las calendas de enero, el cuarto día (es decir, el miércoles) del $42^{\circ}$ año de Augusto, 5500 años después de Adán. Él sufrió en el $33^{\circ}$ año de edad, ocho días antes de las calendas de abril, en el día de la parasceve, del $18^{\circ}$ ańo del reinado de Tiberio, bajo el consulado de Rufo y Rubelión. Es necesario, por tanto, llegar a 6000 años para que llegue el sábado, el reposo, el día santo, en el que Dios "descansó de todas sus obras, que había emprendido" (Gn 2,3). El sábado es el prototipo y la imagen del reino futuro de los santos, cuando éstos reinarán con Cristo, después de que vendrá de los cielos, como ha explicado Juan en el Apocalipsis. De hecho, "el día del Señor como mil años" (Sal 90,4). Por tanto, ya que Dios lo hizo todo en seis días, hay que llegar a 6000 años. Éstos no se han cumplido todavía, puesto que Juan dijo "cinco han caído, uno queda" - es el sexto - "el otro no ha llegado aún” (Ap 17,10), queriendo decir el séptimo, el del descanso".

37 Ireneo, $A d v$. haer. V,25-31.

38 J.J. Collins, Daniel. A Commentary on the Book of Daniel, Minneapolis 1993, $72-$ 89; cf. A. D'Anna, Escatologia e Scrittura in Ippolito: speculazioni cronologiche, antiromanismo, antigiudaismo, ASE 16/1 (1999) 179-196.

39 C. C. BAdilita, L'Anticristo e l'impero romano. Saggio sul «male katechontico», en P. Bettiolo-G. Filoramo (edd.), Il dio mortale. Teologie politiche tra antico e contemporaneo, Brescia 2002, 135-161; ver también Id., Métamorphoses de l'Antichrist chez les Pères de l'Eglise (ThH 116), Paris 2005.

40 Ireneo, Adv. haer. V, 26,1; Hipólito, Comentario a Daniel, 4,7,8. 
brayando su carácter étnico ${ }^{41}$. Es más: Ireneo e Hipólito concuerdan en el introducir la figura del Anticristo, identificándolo con el pequeño cuerno del que habla Daniel 7. En cambio, difieren a propósito de las dos bestias del Apocalipsis y aquí se sitúa la profundidad política de la interpretación de Hipólito. Ireneo, efectivamente, identifica a la bestia que asciende del mar con el Anticristo y a la que asciende de la tierra con su falso profeta, proyectando exclusivamente en el futuro el desencadenamiento del mal. Hipólito, en cambio, identifica al imperio romano con la bestia que asciende del mar y al Anticristo con la bestia que asciende de la tierra. El rol del Anticristo será el de restitutor del imperio, después de su fragmentación, y contemporáneamente de restitutor del reino y del templo de los judíos que, engañados, lo adorarán como el mesías esperado: llegados a este punto, antes de la ruina definitiva obrada por Dios, el destino de los romanos y los judíos, unidos por la oposición en la confrontación con los cristianos, se efectúa bajo el signo de un cumplimiento completamente satánico de sus expectativas. La peculiaridad de Hipólito consiste en relacionar la observación de las señales históricas del presente de Roma a los sucesos escatológicos, especificando su sentido y la trayectoria ${ }^{42}$.

\section{EL INICIO DE LA HISTORIOGRAFÍA CRISTIANA: LA CRONOGRAFÍA}

Hemos visto cómo los cristianos, al menos en su corriente mayoritaria, mantienen la profunda conexión entre Dios y la historia humana, característica del judaísmo. La doctrina de la encarnación del Hijo de Dios constituye una profundización de tal relación porque la historia viene a ser no sólo el lugar de la relación entre Dios y el hombre, sino que el mismo Dios entra, en la persona de Jesucristo, a formar parte de la historia humana. Llama la atención que una de las diferencias entre el símbolo niceno (325) y el niceno-constantinopolitano (381), expresión definitiva de la fe cristiana, consista en la presencia en este último de una precisa coordenada

41 Norelli, Profezia e politica nella ricezione antica dell'Apocalisse: Ippolito e Vittorino di Petovio, Annali dell'Istituto storico italo-germanico in Trento 25 (1999) 315-346, en especial: 326.

42 CF. Norelli, Il presente è storia? Le vicende delle istituzioni terrene tra ascensione e parusia secondo alcuni autori cristiani dei primi due secoli, en Il dio mortale, 107-134, en especial: 131-132. 
cronológica "crucificado bajo Poncio Pilato", ya atestiguada por lo demás en el denominado Símbolo Romano, datable por conjetura en el s. III ${ }^{43}$.

Hemos visto también cómo la primera reflexión cristiana sobre el tiempo histórico parte precisa y paradoxalmente de los cálculos para medir el fin del tiempo: haciéndolo así, confiere espacio y legitimidad al discurso histórico porque proporciona un marco temporal a los acontecimientos, según el esquema hexamilenario. Desde el punto de vista del género literario, al principio los cristianos usan la forma de la cronografía: escritura del tiempo, como su nombre indica ${ }^{44}$. La cronografía pretende, en efecto, ofrecer una relación de una serie de eventos históricos datados con precisión en conexión con un sistema cronológico absoluto de referencia. El que escribe una obra cronográfica tiene siempre un punto de vista que orienta la exposición, de modo que el elenco de los datos no es aséptico, más bien implica una valoración de los mismos. En la cronografía se combinan una hermenéutica implícita y la amplitud de la mirada dirigida a los sucesos colocados en sucesión cronológica: es precisamente esta peculiaridad la que justifica el interés particular por el género mostrado por los cristianos cuando, desde el s. III, comenzaron a reflexionar sobre la historia. En la venida de Cristo, éstos individualizaban el suceso decisivo a partir del cual repensar el devenir de la humanidad: poseían, pues, una fuerte clave hermenéutica y el horizonte cristológico de su pensamiento les condujo a desarrollar una perspectiva decididamente universalista, estableciendo las relaciones temporales de un conjunto mucho más amplio de eventos de los pueblos conocidos con respecto a los antecedentes cronográficos helenísticos, cuya óptica acababa siendo étnicamente autocentrada. La óptica cristiana, en cambio, tiende a reunir a todos los pueblos conocidos bajo un nombre, Jesucristo, que la corriente mayoritaria del cristianismo había substraído a la lógica etnocéntrica.

43 L.H. Westra, The Apostles' Creed. Orign, History and Some Early Commentaries (Instrumenta Patristica et Mediaevalia 43), Turnhout 2002, 67.

44 Aquí inicia una parte de la exposición que es la reelaboración de dos de mis trabajos anteriores: Genere storico. La storiografia di Eusebio di Cesarea, en Costantino I. Enciclopedia costantiniana sulla figura e l'immagine dell'imperatore del cosiddetto Editto di Milano 313-2013. Istituto dell'Enciclopedia Italiana, Roma 2013, II, 59-76 y Le genre historiographique de l'Histoire ecclésiastique, en Eusèbe de Césarée. Histoire Ecclésiastique, 84-111. 
El padre de la cronografía cristiana, Julio Africano, escribe no mucho tiempo después de Hipólito, probablemente en el 221, sus Chronographiae. Figura poliédrica y políglota de intelectual, apreciaba, como colaborador de los Severos que era, la sincronía entre inicio de la monarquía de los Césares y el nacimiento de Cristo, ya conocido de forma positiva por Melitón de Sardes, y que Hipólito había valorado, sin embargo, negativamente. Roma consigue el poder universal en el momento en el que su sistema político se transforma en monárquico y es justamente en esa coyuntura cuando Cristo se encarna. Las Chronographiae, si bien conservadas en fragmentos, se revelan como un trabajo de desarrollo narrativo y de síntesis que comprime la historia universal en un restringido número de libros, cinco en total. Su característica fundamental es el cómputo hexamilenario, del que ya hemos hablado a propósito de Bernabé, Ireneo e Hipólito. Ireneo insertaba el esquema en una perspectiva milenarista, que resulta difusa y dudosa en Hipólito. La misma incertidumbre vemos también en Julio Africano porque no se conservan fragmentos que atestigüen de un modo vinculante la adhesión al milenarismo. En cualquier caso, aunque su interés tenga una apariencia más bien erudita, no puede haber ignorado las inquietudes y la espera de los acontecimientos escatológicos difundida entre los cristianos: es probable que haya intentado enfriarla y encauzarla, como ya había hecho Hipólito, cuyo de Daniel había fijado el nacimiento de Cristo el año 5500 a partir de Adán. Es posible que Africano haya retomado de Hipólito la cronología de Cristo, precisando la muerte el 5531 o 5532 desde Adán y terminando la obra el tercer año del emperador Heliogábalo, es decir, el año 5723 desde Adán: el lapso de tiempo hasta el término de los seis mil años era todavía considerable.

Julio Africano recibe múltiples influjos de la cronografía precedente, pero es la aportación judía la que le permite adquirir con Adán un punto de partida unitario del que parten la pluralidad de historias de los descendientes. En la relectura cristológica el punto de partida unitario se convierte en el preludio del punto central en el que todas las historias convergen, esto es, el nacimiento y la misión de Cristo, en la espera del vencimiento de los tiempos que la intromisión de la ciencia cronográfica griega, integrada en el esquema hexamilenario, permite calcular con precisión. Tras la venida de Cristo, momento central de toda la historia, la narración de los doscientos veintiún años que transcurren hasta la edad presente es muy rápida porque, explica Africano: "después de aquellos sucesos hasta a nosotros, no hay en medio casi nada extraordinario para narrar histórica- 
mente” ${ }^{45}$. Una contracción así del presente permite proyectar toda su edad en el cono de luz de aquella articulación fundamental, en cuanto, especialmente tras la promulgación de la Constitutio Antoniniana en el 212, la acción de los Severos confirmaba el carácter positivo del universalismo de la monarquía imperial y la posibilidad de un encuentro fecundo de Roma con el cristianismo.

\section{De Orígenes a Eusebio: la REVOLUCIÓN HISTORIOGRÁFICA}

De Julio Africano a Eusebio de Cesarea la perspectiva cronográfica cambia decididamente y se da inicio a la historiografía cristiana ${ }^{46}$ : entre medios, no obstante, se coloca la experiencia de Orígenes. Debemos, por tanto, detenernos un instante en este autor, que representa un hito en el pensamiento cristiano antiguo.

También Orígenes, como los gnósticos, considera el mundo actual como resultado de una culpa precósmica y, por tanto, en condición ontológicamente decaída, pero rechaza la idea de dividir a los seres humanos en distintas naturalezas y niega que los espirituales sean consustanciales al mundo divino, como, en cambio, predicaban los gnósticos: para Orígenes, los seres humanos tienen con Dios una relación de creación y no de continuidad ontológica. Además, en contra de los gnósticos y los marcionitas, Orígenes se niega a asignar a dos principios divinos diversos justicia y bondad; en contra de los "ortodoxos", se niega a poner en Dios el aspecto judicial detrás del aspecto misericordioso. Para Orígenes, de hecho, el único Dios es siempre justo y bueno, es más, “es” el bien, mientras que el mal es simplemente no ser, lo que le impide pensar en un castigo eterno (doctrina de la apocatástasis) ${ }^{47}$. Consiguientemente, Orígenes hace iniciar el devenir de las criaturas racionales no desde este mundo (eón), tocado por la desigualdad (inexplicable a la luz del postulado de la coexistencia de justicia y bondad en Dios), sino desde una fase precósmica, en la que se verifica la culpa de las criaturas intelectuales y, por tanto, su diferen-

45 Iulius Africanus. Chronographiae. The Extant Fragments Edited by M. Wallraff with U. Roberto and, for the Oriental Sources, K. Pinggéra. Translated by W. Adler, GCS, N.F. 15, Berlin-New York 2007, F93, 284, 1l. 84-85.

46 M. Wallraff, The Beginnings of Christian Universal History. From Tatian to Julius Africanus, ZAC 14 (2010) 540-555.

47 I. Ramelli, The Christian Doctrine of Apokatastasis. A Critical Assessment from the New Testament to Eriugena, SupplVigChr 120, Leiden-Boston 2013,136-221. 
ciación, desde que eran todas iguales, a causa de las diversas elecciones realizadas por su libre albedrío.

La historia humana se prolonga así, antes y después del mundo actual, en la perspectiva de la multiplicidad de mundos/eones (cf. por ejemplo CIo XIX 87), que induce a relativizar el mundo/eón individual (aunque el eón presente asume una importancia particular porque allí ha nacido Cristo). En definitiva, aun considerando el mundo material como resultado de la culpa de las criaturas intelectuales preexistentes, Orígenes atribuye su creación al único Dios, que lo ha predispuesto con una finalidad redentora. Si la visión de la historia humana en el mundo presente se relativiza por ser un segmento de un acontecer precedente y está destinada a proseguir en otros mundos y condiciones, la tensión escatológica permanece fortísima en Orígenes, que se mueve entre los dos polos del archê y del telos, y describe toda la vida del cristiano como un continuo intento de superación del estadio inmediatamente precedente. Por otra parte, Orígenes, proyectado de este modo en una multiplicidad de mundos, sostiene abiertamente la identificación en este mundo de civilización con imperio romano: aunque todo sustancialmente lealista, cuando se atreve a hipotetizar una conversión de los bárbaros al Logos, ipso facto, la entiende también como su sumisión a las leyes romanas y a la civilización ${ }^{48}$. En una línea completamente consecuente con estos presupuestos, Orígenes rechaza la perspectiva milenarista, es decir, rechaza la idea de que un segmento final de la historia humana, "el milenio", se substraiga al mal de vivir y ofrezca el aspecto glorioso y alegre de la creación. Lo rechaza porque el mundo actual, en su calidad de material, no puede ser el mundo adecuado a aquel que era el ser humano en el proyecto original de Dios, esto es, una criatura privada del cuerpo "pesado" que caracteriza a la vida terrenal. El trasfondo platónico de esta visión es evidente y determina una depreciación objetiva de la existencia terrenal que se mantendrá como característica a largo plazo en el cristianismo. Es, por tanto, absolutamente paradójico que Juan Damasceno, que en el primer capítulo del libro segundo del De fide orthodoxa razona sobre el tiempo, haciendo un elenco de los diversos sig-

48 Orígenes, Contra Celsum, 8,68, ed. M. Borret, Paris 1969 (Sources Chrétiennes 150), 332, 11. 35-40: "Y si es así que si, como dice Celso, todos sin excepción hicieran lo mismo que yo, todos los bárbaros, evidentemente, al aceptar la palabra de Dios, serían los hombres de más ley y los más mansos, desaparecería toda falsa religión y sólo imperaría la cristiana, cosa que acontecerá un día, puesto que el Logos gana para sí más y más almas”. Tr. esp. D. Ruiz Bueno, Madrid 1967, 579. 
nificados atribuibles al término “eón”, atribuya a Orígenes, evidentemente calcándolo sobre Platón, una apocatástasis de mil años.

Eusebio, aun siendo un gran admirador de Orígenes, se detiene en el umbral de los ilimitados horizontes temporales propios de la doctrina origeniana de los mundos sucesivos para concentrarse en la historia de los hombres, por una parte, renovando el planteamiento cronográfico precedente, y por la otra, creando el género literario de la Historia eclesiastica ${ }^{49}$.

En relación a la cronografía nos interesa el modo en que Eusebio, en su Chronicon, demuele la ilusión de abrazar los tiempos del inicio y del fin en una única visión mediante el esquema hexamilenario, sobre el que se había apoyado su predecesor Africano. De hecho, declara: "lo decimos desde el principio claramente a todos, para que no haya réplica: no es posible adquirir un conocimiento seguro de los tiempos. Cada uno lo comprende si se dirige al maestro verdadero que dice: «no es asunto vuestro conocer los tiempos y los momentos que el Padre ha fijado con su autoridad» (Hechos 1,7$)$ ”. Eusebio, pues, no sólo se opone a la división en seis milenios (a excepción de las intenciones de Africano, es un hecho que el cómputo hexamilenario continuó alimentando, especialmente en periodos de crisis, las esperanzas milenaristas y una visión de la historia orientada a escrutar las señales del fin), sino también a la pretensión de dominar el conjunto de los tiempos, el alpha y el omega, que es prerrogativa exclusiva de Dios. $\mathrm{Su}$ proyecto histórico excluye, en consecuencia, justo el inicio fijado por Africano: la cronología de Eusebio no parte de Adán (aunque ocasionalmente haga referencia también a él) porque no puede determinarse el periodo transcurrido en el Edén, pero sí, de manera racional y verificable, desde Abrahán, y la conclusión del recorrido histórico de la humanidad queda abierta, conocida sólo por la providencia divina. El punto en el que se detiene el Chronicon, aunque es provisional, no es casual: se trata del vigésimo año de Constantino, el punto álgido de su reinado, siendo ya el único emperador, y señala también, a contrario, la llegada a buen puerto del cristianismo tras el periodo oscuro de la persecución tetrárquica.

49 S. Morlet- L. Perrone (edd.), Eusèbe de Césarée. Histoire ecclésiastique. Commentaire. Tome I: Études d'Introduction, Paris 2012; ver también: S. Inolowlocki- C. Zamagni (edd.), Reconsidering Eusebius: Collected Papers on Literary, Historical and Theological Issues, SupplVigChr 107, Leiden 2011 y lo último C. Mondello, Eusebio e la storiografia antica. Strategie e tecniche di alterazione nella Praeparatio Evangelica, Pelorias 24, Roma 2017. 
Eusebio en la segunda parte del Chronicon (los denominados Chronici canones, conservados en la traducción latina de Jerónimo, con sus additamenta) había podido demostrar, mediante el rigor 'científico' de una cronografía desplegada en columnas paralelas, la antigüedad de los cristianos, herederos de los profetas hebreos, y la convergencia de las historias de los pueblos en la unidad monárquica del imperio romano, útil para la difusión del mensaje cristiano ${ }^{50}$. Este resultado se pone inmediatamente al servicio del proyecto de la Historia ecclesiastica en diez libros, del que Eusebio, en el prólogo, reivindica, por un lado, la originalidad, considerándola, por otro lado, una ampliación de los Chronici canones. El motivo del reclamo a estos últimos se debe probablemente al orden cronológico de la materia en la Historia ecclesiastica, centrado en la sucesión (diadochê) tanto de los emperadores romanos, como de los obispos de las principales ciudades del imperio. Pero la originalidad de la obra se mantiene por completo gracias precisamente a su intención historiográfica, por tanto, totalmente interpretativa. El juntar la cronología eclesiástica y la romana produce el doble efecto de valorizar el sincronismo entre el nacimiento del imperio romano y el nacimiento del cristianismo y de cristianizar el tiempo histórico, aunque las sucesiones episcopales se coloquen siempre después de las imperiales. De los dos marcadores cronológicos, las sucesiones de los obispos - llamadas apostólicas porque se pensaba que fue un apóstol el que estableció al primer obispo en las principales ciudades - son, en efecto, el elemento más importante ideológicamente: es el primero de los temas que se propone afrontar Eusebio, con respecto a la garantía de la ortodoxia. No olvidemos que la sucesión (diadochê) apóstoles-obispos fue el instrumento, ideado, por lo que sabemos, por Egesipo a mediados del s. II y reutilizado por Ireneo, para superar las dificultades de la sucesión tradicional maestro-discípulo, de la que se habían apropiado las sectas gnósticas con el fin de reivindicar una enseñanza secreta legada a ellos por Jesús ${ }^{51}$. Para Eusebio, las sucesiones episcopales constituyen la garantía de la presencia permanente de Cristo-Logos en las iglesias, lo que comporta la seguridad de una identidad inalterada con respecto a desvia-

50 Chronici Canones es un proyecto editorial deliberadamente innovador: A. Grafton-M. Williams, Christianity and the transformation of the Book: Origen, Eusebius and the Library of Caesarea, Cambridge 2006; O. Andrei, I Chronici Canones di Eusebio di Cesarea. Una rivoluzione cronografica, Adamantius 16 (2010) $34-51$.

51 C. Antonelli, Hégésippe chez Eusèbe. Histoire ecclésiastique, IV, 21-22: $\triangle I A \Delta O X H^{\prime}$ et origine des hérésies, Apocrypha 22 (2011)185-232. 
ciones extrañas (las herejías) y a los contragolpes externos. Las sucesiones se convierten así en el elemento cualitativamente primario en el ámbito de los distintos componentes de la parrilla temática. De este modo, Eusebio impone una jerarquía de relevancias, de por sí interpretativas, que hacen de hilo conductor de la narración, que de otro modo peligrarían de naufragar por causa de la mole de noticias transmitidas por las diversas fuentes y necesitadas de organización.

Con respecto a la cristianización de los tiempos, en la Historia ecclesiastica se nota que la amplitud del tiempo histórico viene delimitada a partir de los apóstoles y de sus sucesores, es decir, por los efectos de la venida a la tierra de aquel Salvador que habría sellado con su misericordia la victoria de los cristianos en el tiempo de la persecución. La novedad de esta consideración temporal saca a relucir la objeción con la que los cristianos se topaban desde siempre: el ser unos innovadores, por tanto, una desviación sea con respecto a Israel, sea con respecto a los cultos tradicionales del imperio. Eusebio es bien consciente de ello y predispone la respuesta. En el primer libro hace seguir el prólogo de un resumen de carácter doctrinal sobre la economía y la teología de Cristo, que posteriormente Eusebio denomina тœок $\alpha \tau \alpha \sigma \kappa \varepsilon v \eta ́$, término retórico para indicar el prefacio de una narración. Tal prefacio tiene una función completamente central para

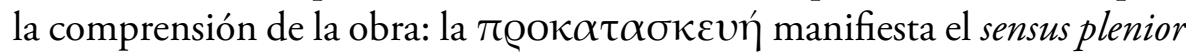
de la narración porque reconduce la historia de los cristianos según la voluntad de Dios, a través de la exposición de la doble naturaleza de Cristo que, como Logos y Sabiduría preexistente, es la segunda causa del universo junto al Padre y, como Dios hecho hombre, es artífice de la salvación. Además, la antigüedad primordial de Cristo en cuanto Logos es garantía de la antigüedad de los cristianos, sus seguidores directos desde el momento de su manifestación terrenal, mientras que los profetas y los justos anteriores sólo lo pudieron venerar en imagen. No se escapa el planteamiento claramente polémico de Eusebio: la novedad y el carácter desviante del cristianismo formaban parte del bagaje acusatorio producido por los adversarios, como Porfirio o Hierocles, que recientemente habían puesto en tela de juicio la legitimidad histórica de los cristianos. El objetivo epistemológico y el objetivo apologético resultan íntima e indisolublemente unidos en la Historia ecclesiastica, al igual que en los Chronici canones. Aunque, a diferencia de la anterior obra cronográfica, aquí Eusebio puede explayarse en la argumentación, situando abiertamente el fundamento de la historia eclesiástica en el plano salvador de la economía de Cristo "que es más divi- 
na de lo que pueda parecer a muchos". En la тœок $\alpha \tau \alpha \sigma \kappa \varepsilon v \eta ́$, por tanto, se enuncia la clave de lectura global de la historia humana, regida por la providencia, en función de los cristianos, a través de dos disposiciones: el crecimiento imparable del nombre cristiano, para contrarrestar al cual la acción del demonio se desencadena en diversas formas, aunque en vano, y un sistema de premios/castigos que llega siempre a concretarse, pero según tiempos y modos impredecibles para el hombre.

Mientras los Chronici canones demostraban la actuación providencial, evidenciando a largo plazo la dirección global de la historia de los pueblos y contrayendo el presente para que fuese fácilmente comprendido sobre el trasfondo de la historia universal, en la h.e., que toma en consideración solamente un segmento, si bien el más importante, de la historia universal, los hechos del pasado más reciente y del presente se dilatan en los tres libros, que narran sólo diez años, a diferencia de los siete libros que cuentan poco menos de trescientos ańos: el motivo de la desproporción reside en el hecho de que estos diez decisivos años son justamente la demostración más elocuente de las dos disposiciones puestas en acción por la providencia a lo largo de toda la historia. En virtud de la fe en la providencia, adquiere un sentido más restringente la sentencia historia magistra vitae, común en la historiografía clásica y compartida por Eusebio, que confirma la utilidad de su obra para "aquellos que quieran obtener la buena enseńanza de la historia”. La suya ofrece la enseñanza más grande posible porque en ella son Dios mismo y su Logos los que actúan: la visión histórica de Eusebio es precisamente una teología de la historia gobernada por el desplegarse del Logos. Con respecto a la historiografía griega, la sustitución del destino o suerte por la providencia es señal de una nueva comprensión de la relación de los hombres con lo sobrenatural. Predomina en los griegos el sentido de la inevitabilidad de lo que está destinado al hombre, más allá de su comprensión y de su deseo: la autonomía de la decisión humana que, no obstante, subsiste, se sitúa en un marco sobrenatural incontrolable y el consecuente nexo entre las acciones y la correspondiente retribución es lábil. En la visión eusebiana, que hereda y sistematiza a propósito el convencimiento hebreo, ese nexo es, en cambio, restringente porque Dios es a la vez previsor y justo. Un plan divino hay detrás de cada acontecimiento y Dios permite al diablo actuar, como prueba o como castigo para su pueblo, con el único fin de llevar a término su plan benévolo. Con respecto a los hebreos, las diferencias tienen que ver tanto con el cambio en sentido universalista del concepto de pueblo de Dios, como con la involucración 
aún más directa de Dios en la historia humana a través de la encarnación del Logos, como decía al inicio de esta disertación.

Visto muy desde arriba y en conjunto, la concepción histórica de Eusebio es realmente positiva, por el hecho mismo de que la historia está guiada por la providencia. Sin embargo, si observamos más de cerca, constatamos que el libre albedrío del hombre, afirmado con decisión por Eusebio, pone siempre al hombre en el peligro de caer bajo el poder de los demonios por causa de sus malas elecciones y de activar el castigo divino. Es más, la condición terrenal es para Eusebio, como lo era para Orígenes, una condición ontológicamente decaída: la historia humana, objeto en apariencia exclusivo de su atención, se enmarca, como percibimos por indicios discretos pero significativos, en el contexto negativo constituido por la idea de una caída ontológica (h.e. 1, 2, 18), y, sin embargo, en una apreciación decididamente limitada de las realidades terrenas. Bien vista, la antropología eusebiana, y prescindiendo de la sospecha de adhesión a la teoría de la preexistencia, se presenta como radicalmente dualista: a cada paso vienen contrapuestos el hombre verdadero, es decir, el alma, hecha a imagen y semejanza de Dios, y el cuerpo, revestimiento terrenal, unido a ella como "animal de carga" y "esclavo" para la vida terrenal" ${ }^{52}$ Leamos la siguiente definición de hombre: "no es un ser unigénito ni viene a ser de una sola naturaleza, sino que es el resultado de la unión de dos contrarios, cuerpo y alma, el uno dado al alma como instrumento accidental, la otra, sustancia inteligible subsistente siguiendo una razón preordenada (N.B. ¿una referencia a la preexistencia de las almas?), el uno corruptible, la otra incorruptible, el uno mortal, la otra inmortal" 53 . A la luz de este planteamiento, la raíz profunda del antimilenarismo de Eusebio, casi obsesivo en toda la Historia eclesiástica, no parece deberse a la sobrevaloración del reinado constantiniano (también él sintió admiración sincera), sino al pesimismo subyacente en su valoración de la vida terrena. Él recupera, por tanto, la historia de los cristianos como pueblo universal en clave providencial, sobre un fondo de pesimismo que, sin embargo, ha perdido ligeramente la tensión escatológica que se notaba en Orígenes. La vida de aquí abajo es para vivirla bajo la égida del emperador, que asume la función

52 Praeparatio evangelica, VII,17,3 e 18,6; SCh 215, 256 y 260.

53 Praeparatio evangelica, VI,6,26, SCh 266,140. 
vicaria de Cristo sobre la tierra ${ }^{54}$, protegiendo a la Iglesia y difundiendo el evangelio, durante la espera de la muerte que dará paso a una vida mejor.

La vida terrenal se concibe ahora sólo en función de una vida celeste, en la que las esperanzas "humanas" del corazón vienen desfiguradas hasta el punto de no ser ya reconocibles.

\section{CONCLUSIÓN}

La reflexión cristiana sobre el tiempo y la historia surge de las dificultades relacionadas con el problema del retraso de la parusía de Cristo, de la persistencia del mal y con el sufrimiento de los justos en el mundo.

En el siglo segundo emergen dos visiones opuestas: la devaluación de la historia humana propuesta por el pensamiento gnóstico; y la redención de la historia mediante el reino terrenal de Cristo con los justos propuesta por los milenaristas. Incluso el esquema que divide la historia en seis milenios está inicialmente relacionado con la necesidad de calcular el tiempo final.

Cuando, con Eusebio, prevalece el trasfondo platónico, la historia, ahora desprovista de cualquier predicción cronológica acerca del final de los tiempos, puede narrarse en el marco de la dialéctica entre la divina providencia y la libre voluntad de los seres humanos.

54 De laud. Const. VII,13. 